\title{
Determination AHP Analysis of the Virtual Stage-Gate Process in the Global Scale Automotive Design
}

\author{
Fuat Ali Paker1, Cem Alppay¹, Begüm Sertyesilisik² \\ ${ }^{1}$ Industrial Design Department, Istanbul Technical University, Istanbul, Turkey \\ ${ }^{2}$ Architecture Department, Istanbul Technical University, Istanbul, Turkey \\ Email: pakerf@itu.edu.tr
}

How to cite this paper: Paker, F.A., Alppay, C. and Sertyesilisik, B. (2018) Determination AHP Analysis of the Virtual Stage-Gate Process in the Global Scale Automotive Design. World Journal of Engineering and Technology, 6, 929-945. https://doi.org/10.4236/wjet.2018.64062

Received: October 27, 2018

Accepted: November 27, 2018

Published: November 30, 2018

Copyright $\odot 2018$ by authors and Scientific Research Publishing Inc. This work is licensed under the Creative Commons Attribution International License (CC BY 4.0).

http://creativecommons.org/licenses/by/4.0/

\begin{abstract}
In this study, it is aimed to determine the ranking importance levels of the stages to be taken into consideration for new product development on a global scale in the automotive design process. New product design activity and stage-gate process differences between local automotive firms (serial production factory and stage-gate department in Turkey) and global automotive companies (serial production factory and stage-gate department in Turkey) are examined comparatively in the research area. In the automotive industry, which has been developing for a century, the question of how the local company products operating in the last sixty years have not been able to spread globally or how to develop global products is the background question of the research. For this purpose, one on one interviews were held with the managers of 3 national and 3 international automotive companies, who worked in the same region and who had previously designed a new vehicle, with design and product development departments. According to the data obtained by the AHP (Analytic Hierarchy Process) in the automotive design process, the importance of the criteria that should be taken into account for global product development has revealed. According to the results of the study, it was found that design validation stages were the most important globalization criterion in automotive design process as a new study area. In the comprehensive survey of the study, no other publication has been encountered to measure or evaluate the stages in the automotive design and new product development process in other sectors, including the vehicle industry. As in every industry sector, in the automotive industry, with the new product companies provide market development or competitive advantage. The new product is the life channel of a company and in the realization of this new vehicle; the disciplines of the automotive industry are formed by a hundred years of experience.
\end{abstract}




\section{Keywords}

AHP, Stage-Gate Process, Design Verification, Automotive Industry, Design Process

\section{Introduction}

New vehicle design or product development stages are the most important building blocks for the sustainable regional expansion of automotive companies, along with their competitiveness in global markets. In order to understand the value of the design phases in firm performance or the role of design in general, comprehensive research is carried out [1] [2]. The new product, which has completed the stages of vehicle design, plays an active role in the growth and shrinkage or expansion of automotive companies in the new markets with the impression it gives to different users in different regional markets. Therefore, it is difficult to distinguish the contribution of vehicle design financially in the market share of the new product [1] [3]. The new vehicle design, starting with the decision to consolidate or privatize the opportunities in the markets that are targeted and expected to spread, extends to the control steps, including the verification of the product under these defined conditions. The functional meaning, conceptualization, definition and testing of the system formed with the new product constitute the basic structure of the design activities [4] [5] [6] [7]. In order to understand the design, validation and development process in question, the importance of these stages specific to the automotive sector, as well as the determination of interdisciplinary collaborations, provides significant orientations. The development of a single automotive component with a focus on innovation initially influences the redesign of multiple connected vehicle parts [8] [9] [10]. Therefore, the fact that the vehicle sales price, vehicle usage capacity, number of production, and similar factors, which constitute the output of the new product design process in the automotive industry, take place in the same evaluation formula, reveals the calculation of all measures and impact. In the new product development activities of automotive industry firms, the decisions of designing, validating, modifying, testing, creating, positioning or arranging such process stages minimizes the uncertainties of the ultimate vehicle's global success and minimizes the risk. In this sense, the effectiveness of the development steps or the performance of the new product design stages, including the production process related to the overall structure is established according to all criteria [11] [12]. The use or selection of these processes constitutes the factors affecting the market success of the new vehicle design. In order to verify the final design for the different or the same market during the development of the new vehicle, and to protect the data by archiving it, to update it over time, the process and the regional distribution of the automotive company product are an increasing chart. Vehicle design in the automotive industry has many current 
stages of development like, product verification on the new technologies to virtual assembly. The rapid adaptation of new technologies in the automotive industry shows the dynamism of scientific diversity in the interdisciplinary new product development process in this sector [13] [14]. For this purpose, the definitions, functions and identification of the new product development processes in the automotive industry and the determination of the situation by identifying the common phase collaborators reveal the needs of vehicle design activities. In the study, the formation of new vehicles in the automotive industry was evaluated under the interactions of three different main development stages. Although design and design verification constitute two different product development titles, considering the stages of product development, a nested holistic structure is revealed. These process components were compared in the same region, in the same market, manufacturing with same class vehicle, dependent on global brand (MF) and independent local (BF) automotive companies were examined and the stages were compared [3]. In the study, six companies, which were evaluated under two groups in the automotive main industry, were visited in their factories and interviews were conducted. Sixty product development managers who are the employees of six firms who participated in the study with special permissions were identified with a defined code system within the framework of the protection of ethical values. In the application part of the study, the new vehicle design stage definitions obtained from the field study, design validation and product development process matched the importance of common collaborators, firm-oriented criteria are determined by AHP method. The research conducted in the automotive industry has been completed with a discussion section and a result section which includes field limitations and possible future work suggestions.

\section{Virtual Design Verification Phase in the Stage-Gate Process}

This research identifies the common partnerships of automotive design activities as well as the design validation stages formed in the new product development stages. The design verification stages in the commercial vehicle industry control the suitability of each new concept from the steps of the automotive design activity according to the project objectives. Within the scope of the product design activities, 24 flow steps matching 14 stages and product development steps have been defined to 3 local (BF1, BF2, BF3) and 3 global (MF1, MF2, MF3) automotive companies. In the field study findings, the design phase of the 38 stages, 6 in the first 14, and 8 in the remaining 24 steps were determined. Considering the development of the new vehicle, these design activities and design validation stages were evaluated with the AHP method [3].

In the new project formation, vehicle design activities, usage or idea sketch, 2D product sketch and vehicle technical aspects, concept development are formed in the initial stage of the product development process in automotive industry. Verification steps mean "design that fulfils the defined function" [15]. 
Design validation studies provide the next step in the product development process by comparing input requirements to determine whether the automotive design activity outputs meet project objectives. In other words, it includes a series of tests conducted for the validity of the positive response of different products in different environmental factors [16] [17]. In the new concept development, the vehicle development process, which extends to the detail design of the parts of the main structure applied by using 3D CAD programs, is tested with different analysis of different scientific approaches. The design validation approach in the automotive industry includes new functions, new forms, new ideas, and testing on the main structure. Under the conditions of heavy competition, the stage of product development, which will add value to the new product, will provide a market spread, and phase-out of this information under the main structure with defined procedures and time interval. The design validation approach controls all production processes, from the measurement of different scientific approaches under environmental factors, to the parts connection details used in assembly lines [12] [18]. The design validation studies that will be carried out at the beginning of the basic process prevent the modifications that will occur in the continuation of the process. Vehicle design activities and product development process constitute the organization of a productive efficient resource management. The process of optimizing or determining the stages of this process, and its management, provides a direct proportion to the success of the market. The reason why design validation studies are considered as a new generation approach in the product development process is the result of the numerical easy synthesis of the conceptual outputs and the transfer of alternative solution suggestions or boundary conditions through computer aided visual methods [19] [20] [21]. International ministries of industry adopt the results of computer analysis for the safety factors of a similar vehicle (ECE, EEC, EC, REG, SAE): collision test, tipping test, self-weighting test of the superstructure. The fact that these structural tests have been carried out by physical vehicles to date show the rapid development of design validation studies in product development stages. In the design activities, the visual development of the strength verification results of the main structure formed by new concepts form the boundary information for the next vehicle design project. Prior to new generation design validation approaches, Verganti (1997) argued that it would play an important role in testing and advancing the concepts of physical prototypes that will be produced in the early stages of vehicle design process [22]. In today's design verification studies, virtual prototype, virtual assembly, real-time virtual product experience and similar stages are used to explore or test new ideas and concepts with the same dynamic thinking approach [13] [14] [23] [24].

\section{Determination of Vehicle Design Stages Using AHP Method}

In the design verification and development processes in the automotive industry, determining the impact values of the stages that guide the final product has im- 
portant consequences for the basic flow construction. In the study, considering the impact assessment of the design, verification and development processes in question, it has been proposed to collect qualitative and quantitative factors under a result-oriented common formula. Within the scope of automotive companies, data such as determining the market success and spread of the new product, determining the sales price, usage capacity or production quantities of the vehicle passed through the design stages are carried out with quantitative information. In the light of this quantitative information, fuzzy logic method is preferred to evaluate the formation stages of the new vehicle or to examine the effect of qualitative automotive design activities on the final product. AHP mathematical model, one of the fuzzy logic methods developed by Saaty (1980), was created to evaluate qualitative and quantitative criteria under the same roof [25]. This study focuses on the effect of new vehicle design stages in the automotive industry on the competitiveness of the final product in competition, in terms of market success, rather than the comparison of fuzzy logic methods (AHP, Topsis, Vikor, Kma, Dematel, Promeet, Electre, Gra etc.). Near this research, when the studies using the AHP method are examined: In project selection [26] [27] [28] [29], in the selection of project technology [30] [31], in the decision of project design with the selection of digital technology [32] [33], in the decision to choose equipment and new product [34]-[39], similar analysis models are used. Nowadays, it has become more effective to increase competitiveness, profitability and continuity or to provide global dissemination by using non-cost-driven business processes [40]. The main condition for achieving this is the awareness of the business processes and variables, as well as the good management of these processes [41]. Process analysis has the steps of; process mapping, implementation of process analysis, evaluation of process analysis [42] [43].

\section{Evaluation of Product-Oriented Design Phase with AHP Method}

In this study, the design stages for the new vehicle development problem on a global scale were examined by comparative one on one interview at the competing automotive firms' level. In addition, for the solution of the problem and testing of the findings, the product sales performance of these automotive companies competing in the same market was analyzed. Within this scope, vehicle design processes of six different automotive companies were examined and each new product development phase was compared and tested with final market results. In our country, the selection of the automotive company including the manufacturing and design processes on the same class product was evaluated under two groups as global brand (MF) and independent local brand (BF). From each automotive company, ten development managers, and four company managers and in totally 84 company employees were interviewed. The companies involved in the study within the framework of the protection of ethical values and confidentiality agreements between companies are defined by the code sys- 
tem above. According to the results of the product sales performance and the results of the one on one interview of the companies in question, new product development phase differences are numerically explained in Figure 1.

The first five articles of the automotive companies in Figure 1 (product sales performance information) were obtained from the Ministry of Industry database and the last five items were obtained from one on one participant interviews. In the field work of the study, with the participants, current or hand sketch process mapping, the design, verification, development stages of the automotive companies, together with the common step collaborations were formed in detail (Figure 2).

During the one on one interviews, the participants were asked to set the criteria in Figure 2 according to their importance for the global new product design and to evaluate each criterion over 5 points. The participants were asked to write the most preferred development stage to the 1st place and the least effective design step to the 5th place for the globalization of the new product. The remaining stages and criteria which are not preferred by the participants are also positioned in the last ranks (Figure 3). In this way, a stage-firm matrix was created to show which stage each participant preferred for the globalization of the new product due to which criteria (Figure 3 ). Therefore, according to the new product design stages of the six automotive firms, the necessary inputs have been created for the steps of the company managers (Figure 3 ).

The product sales performance information, along with the matrices obtained from the field study, has been calculated in the EC software (Expert Choice software for the AHP) at the level of alternative vehicle or firm, under main and sub criteria, after being arranged in the company specific. Therefore, AHP method with the EC software, the stages of the new vehicle design, the importance of these criteria, respectively, at the level of automotive companies, the final product-oriented result was obtained. According to the results of one on one interview, firstly consistency ratio calculations were taken into consideration in the decision matrices obtained from 84 participants, 50 participants were observed to be consistent, and it was deemed appropriate to consider these decision matrices. The most important factor in the mathematical model is to obtain the

\begin{tabular}{|l|c|c|c|c|c|c|}
\hline \multicolumn{1}{|c|}{ Research Area: } & \multicolumn{6}{c|}{ Global (3 MF) and Local (3 BF) *Automotive Company in Turkey } \\
\hline & MF1 & MF2 & MF3 & BF1 & BF2 & BF3 \\
\hline Company Profile & Global & Global & Global & Local & Local & Local \\
\hline Vehicle Segment & Minibus & Minibus & Minibus & Minibus & Minibus & Minibus \\
\hline Marketing Price (TL) & 95.000 & 90.000 & 85.000 & 150.000 & 120.000 & 110.000 \\
\hline Production Amount (2017) & 36.000 & 5.498 & 2.642 & 7.000 & 5.000 & 2.100 \\
\hline Passenger Capacity & 16 Seat & 14 Seat & 12 Seat & 18 Seat & 16 Seat & 14 Seat \\
& 6 Stand & 4 Stand & & 8 Stand & 6 Stand & 4 Stand \\
\hline Product Life Cycle (Year) & 5 & 6 & 8 & 10 & 12 & 14 \\
\hline Project Duration (Month) & 48 & 47 & 48 & 24 & 23 & 24 \\
\hline $\begin{array}{l}\text { Product Development Phase } \\
\text { and Employee }\end{array}$ & 24 Stage & 20 Stage & 16 Stage & 12 Stage & 10 Stage & 8 Stage \\
\hline $\begin{array}{l}\text { Vehicle Design Stage and } \\
\text { Employee }\end{array}$ & 1.300 & 800 & 270 & 72 & 60 & 40 \\
\hline Design Verification & 30 Stage & 12 Stage & 10 Stage & 8 Stage & 6 Stage & 4 Stage \\
\hline *MF and BF Automotive Company Group: New stage-gate process and serial production application in Turkey \\
\hline
\end{tabular}

Figure 1. Product values of the automotive companies that make up the comparison. 


\begin{tabular}{|c|c|c|c|c|c|c|c|c|c|c|c|}
\hline & \multirow{2}{*}{\multicolumn{2}{|c|}{ Vehicle Design Stage }} & \multicolumn{6}{|c|}{ Automotive Company Profile/ Exten } & \multirow{2}{*}{\multicolumn{2}{|c|}{ Software }} & \multirow{2}{*}{$\begin{array}{c}\text { Occupa } \\
\text { tion }\end{array}$} \\
\hline & & & \begin{tabular}{|l|l|} 
MF1 & MF \\
\end{tabular} & \begin{tabular}{|l|l|} 
F2 & MF \\
\end{tabular} & \begin{tabular}{l|l} 
F1 & BF \\
\end{tabular} & \begin{tabular}{l|l} 
F1 & BF \\
\end{tabular} & \begin{tabular}{|l|l|} 
F2 & BI \\
\end{tabular} & Phase & & & \\
\hline \multicolumn{3}{|c|}{ 2D Idea, Doodle } & + & + & - & - & - & V.D & \multicolumn{2}{|r|}{ C.-A.D.-P.S } & E. \\
\hline \multicolumn{3}{|c|}{ 2D New Vehicles Sketch } & + & + & + & + & + & V.D & \multicolumn{2}{|c|}{\begin{tabular}{l|l} 
V.D. & A.C.-A.D.-P.S
\end{tabular}} & E., G. \\
\hline \multicolumn{3}{|c|}{ 2D Technical Drawing } & + & + & + & + & + & \multicolumn{3}{|c|}{\begin{tabular}{l|l} 
D.V. & A.S.-D.C.-S.W
\end{tabular}} & E., T. \\
\hline \multicolumn{3}{|c|}{ 2D Presentation -Approval } & + & + & - & - & - & V.I & D. A.C. & -A.D.-P.S & E., G. \\
\hline \begin{tabular}{l|l}
5 & $3 \mathrm{DC}$ \\
\end{tabular} & Clay Model & & + & + & - & - & - & D. & \begin{tabular}{l|l} 
V. & G.C \\
\end{tabular} & C.-D.C.-N.X & E., H.,S \\
\hline $6 \quad 3 \mathrm{DS}$ & Scanning Vehicle $\mathrm{Cla}$ & y Model & + & + & + & + & - & D.V & \begin{tabular}{l|l} 
V. & G.C \\
\end{tabular} & C.-D.C.-N.X & E., M. \\
\hline \begin{tabular}{l|l|}
7 & $3 \mathrm{DC}$ \\
\end{tabular} & CAD Vehicle Model & & + & + & & + & + & V.D & \begin{tabular}{l|l} 
D. & A.S.
\end{tabular} & -D.C.-S.W & E., M. \\
\hline \begin{tabular}{l|l|}
8 & $3 \mathrm{D}$ \\
\end{tabular} & Virtual Prototype & & + & - & - & & - & D. & \begin{tabular}{l|l} 
V. & S.C. \\
\end{tabular} & C.-V.R. & E., M. \\
\hline \begin{tabular}{l|l|}
9 & $3 \mathrm{D} \mathrm{F}$ \\
\end{tabular} & Rapid Prototype & & + & + & + & + & - & D. & \begin{tabular}{l|l} 
V. & G.C \\
\end{tabular} & C.-D.C.-N.X & E., M. \\
\hline \begin{tabular}{l|l|}
10 & $3 \mathrm{D} \mathrm{I}$ \\
\end{tabular} & Interior/Exterior Trin & Design & + & + & + & & + & V.I & \begin{tabular}{l|l} 
D. & R.C \\
\end{tabular} & C.-D.C.-S.W & E., M. \\
\hline \begin{tabular}{l|l|}
11 & $3 \mathrm{D} \mathrm{I}$ \\
\end{tabular} & Int./Ext. Functional P & rototype & + & + & + & + & + & $\overline{\mathrm{D} .}$ & \begin{tabular}{l|l} 
V. & R.H \\
\end{tabular} & H-D.C-S.W & E., M. \\
\hline \begin{tabular}{l|l|}
12 & $3 \mathrm{D}$ \\
\end{tabular} & Virtual Production $\mathrm{A}$ & sembly & + & + & - & - & - & D. & V. D.C. & .-N.X.-S.W & E., M. \\
\hline \begin{tabular}{l|l|}
13 & $3 \mathrm{D} \mathrm{A}$ \\
\end{tabular} & A Class CAD Surface & & + & + & - & - & - & V.I & D. A.S. & -D.C. & E., T. \\
\hline \begin{tabular}{l|l}
14 & $3 \mathrm{DC}$ \\
\end{tabular} & CAD Vehicle Model & Transfer & + & + & + & + & + & V.L & D. R.H- & I-D.C & T., M. \\
\hline Code & Software & & Code & & Softw: & vare & & Code & & Occupatio & \\
\hline A.C. & Autodesk Alias C & ncept & N.X. & Siemen & ns Uni & igraph & hics & E. & Indus & strial Designer & \\
\hline A.D. & Autodesk Alias D & esign & R.C. & & inocer & ros & & T. & Drafts & tsman & \\
\hline P.S. & Adobe Photoshop & & G.C. & Geoms & agicCir & imatrol & & H. & Sculp & ptor & \\
\hline A.S. & Autodesk AutoSt & dio & V.R. & Chaos & Softw & vare $\mathrm{VF}$ & Ray & G. & Graph & her & \\
\hline D.C. & DassaultCatia & & K.S. & KeySh & & & & S. & Ceran & micist & \\
\hline S.W. & Dassault Solid Wc & rks & S.C. & Autode & lesk Sh & ow $\mathrm{Ca}$ & ase & M. & Mech & hanical Engine & \\
\hline Code & & hase & & & Code & & & & & hase & \\
\hline V.D. & Vehicle I & esign Proc & cess & & D.V. & & & & esign Ve & erification & \\
\hline & Product Developme & nt Process & Auton & motive & Comp & pany $\mathrm{PI}$ & rofile/ & Exten & & & \\
\hline & (Stage-Gate Pr & cess) & MF1 & MF2 & MF1 & BF1 & BF2 & BF3 & Phase & upatio & \\
\hline \begin{tabular}{l|l}
1 & $S$ \\
\end{tabular} & Strategic Project Man & agement & + & + & - & - & - & - & PLM & MM, EM, K & \\
\hline \begin{tabular}{l|l}
2 & $\mathrm{R}$ \\
\end{tabular} & Regional Vehicle Ma & hagement & + & - & + & - & - & - & PLM & MM, EM, K & \\
\hline \begin{tabular}{l|l}
3 & $V$
\end{tabular} & Vehicle Architecture & & + & + & + & - & - & - & PLM & MM, EM, K & \\
\hline 4 & Project Management & & + & + & + & + & + & + & PLM & $\mathrm{MM}, \mathrm{EM}, \mathrm{K}$ & \\
\hline \begin{tabular}{l|l}
5 & $V$ \\
\end{tabular} & Value Eng. & & + & + & + & + & - & - & MRP & $\mathrm{MM}, \mathrm{EM}, \mathrm{K}$ & \\
\hline \begin{tabular}{l|l}
6 & $V$ \\
\end{tabular} & Viability of New Tec & hnologies & + & - & - & - & - & - & CAD & MM, UM, K & \\
\hline \begin{tabular}{l|l}
7 & $F$ \\
\end{tabular} & Functional BIW Eng. & & + & + & + & - & - & - & CAE & MM, UM, K & \\
\hline \begin{tabular}{l|l}
8 & $\mathrm{E}$
\end{tabular} & Elc. \&Elctr. System & & + & + & + & + & + & + & EAD & EM, TM, BI & \\
\hline \begin{tabular}{l|l}
9 & $C$ \\
\end{tabular} & Chassis Cowl Eng. & & + & + & + & + & + & + & CAD & MM, UM, K & $\mathrm{KM}$ \\
\hline \begin{tabular}{l|l}
10 & $\mathrm{~B}$ \\
\end{tabular} & Body Eng. & & + & + & + & + & - & - & CAD & MM, UM, K & $\mathrm{KM}$ \\
\hline \begin{tabular}{l|l}
11 & $R$ \\
\end{tabular} & R\&D Purchase Eng. & & + & + & - & - & + & + & ERP & $\mathrm{MM}, \mathrm{EM}, \mathrm{K}$ & \\
\hline \begin{tabular}{l|l}
12 & $\mathrm{R}$ \\
\end{tabular} & R\&D Manufacturing & Eng. & + & + & + & + & + & + & MRP & MM, EM, K & \\
\hline \begin{tabular}{l|l}
13 & In \\
1
\end{tabular} & Interior / Exterior Tri & n Eng. & + & + & + & + & + & + & CAD & $\mathrm{MM}, \mathrm{UM}, \mathrm{K}$ & \\
\hline \begin{tabular}{l|l}
14 & $\mathrm{~V}$ \\
\end{tabular} & Vehicle Packaging Er & & + & - & - & - & - & - & CAE & $\mathrm{MM}, \mathrm{EM}, \mathrm{K}$ & \\
\hline \begin{tabular}{l|l}
15 & $\mathrm{~V}$ \\
\end{tabular} & Vehicle Ergonomic E & & + & + & + & - & - & - & CFD & $\mathrm{MM}, \mathrm{EM}, \mathrm{K}$ & \\
\hline \begin{tabular}{l|l}
16 & In \\
\end{tabular} & Interface Control Eng & & + & + & - & - & - & - & $\mathrm{EAD}$ & $\mathrm{MM}, \mathrm{EM}, \mathrm{K}$ & $\mathrm{KM}$ \\
\hline \begin{tabular}{l|l}
17 & $\mathrm{~T}$ \\
\end{tabular} & Thermal Aerodynami & cs Eng. & + & + & - & - & - & - & CFD & $\mathrm{MM}, \mathrm{UM}, \mathrm{K}$ & $\mathrm{KM}$ \\
\hline \begin{tabular}{l|l}
18 & $\mathrm{P}$ \\
\end{tabular} & Power Chassis Cowl & Eng. & + & + & + & + & + & - & CEA & MM, UM, K & $\mathrm{KM}$ \\
\hline \begin{tabular}{l|l}
19 & $\mathrm{~V}$ \\
\end{tabular} & Vehicle Structural An & alysis Eng & + & + & + & + & + & - & $\mathrm{CAE}$ & MM, UM, K & KM \\
\hline \begin{tabular}{l|l}
20 & $V$ \\
\end{tabular} & Vehicle Bodywork En & & + & + & + & - & + & + & $\mathrm{CAE}$ & MM, UM, K & $\mathrm{KM}$ \\
\hline \begin{tabular}{l|l}
21 & $\mathrm{P}$ \\
\end{tabular} & Prototype Verification & Eng. & + & - & - & - & - & - & CMM & MM, UM, K & $\mathrm{KM}$ \\
\hline \begin{tabular}{l|l}
22 & $R$ \\
\end{tabular} & R\&D After Sales Eng & & + & + & - & + & - & - & ERP & MM, EM, K & $\mathrm{KM}$ \\
\hline \begin{tabular}{l|l}
23 & $V$ \\
\end{tabular} & Vehicle Test Manage & nent & + & + & + & + & + & - & CMM & MM, EM, K & $\mathrm{KM}$ \\
\hline \begin{tabular}{|l|l|}
24 & $R$ \\
\end{tabular} & Reg. \&Hom. Eng. & & + & + & + & + & - & + & PLM & $\mathrm{MM}, \mathrm{EM}, \mathrm{K}$ & $\mathrm{KM}$ \\
\hline Code & Definition & Code & & Soft & tware & & & Code & & Occupation & \\
\hline Eng. & Engineer & CAD & Catia,Ur & nigraph & hics, S & Solidwc & rork & MM & Mech & hanical Engine & \\
\hline Elc. & Electrical & CMM & Cimatro & on, Sim & uulator, & r, Quin & ndos & EM & Indus & strial Engineer & \\
\hline Electr. & Electronical & CAE & Matlab, & Patran & 1, Nastr & & & EM & Electr & trical Engineer & \\
\hline Reg. & Regulation & CEA & Ansys, $A$ & Abaqus & & & & TM & Electr & ronical Engine & eer \\
\hline Hom. & Homologation & CFD & Fluent, & T-Gam & bit & & & BM & Comp & puter Enginee & \\
\hline BIW & Body In White & EAD & Proteus, & Mento & or Grap & iphics & & UM & Aircr: & aft Engineer & \\
\hline M & Month & M-ERP & $\mathrm{SAP}, \mathrm{Or}$ & racle A & Agile, L & Dynam & mics & $\mathbf{K M}$ & Mech & hatronics Engi & ineer \\
\hline
\end{tabular}

Figure 2. Design verification and development stages of automotive companies participating in the research.

final significance value of the sub-criteria as a result of the sum of the primary criterion based on the hierarchical structure as compared to the alternative automotive product comparison data. The criterion value of each stage that affects the global development of the new product is tested by the market's sales information. This final sub-criterion and AHP model are presented in Figure 4.

With the calculated effect rates, the price and capacity of the vehicle, the main criteria, which are included in the mathematical model used to determine the 


\begin{tabular}{|c|c|c|c|c|c|c|c|c|}
\hline Key Criteria & Rate & Sub Criteria & MF1 & MF2 & MF3 & BF1 & BF2 & BF3 \\
\hline \multirow{2}{*}{ MARKETING PRICE } & \multirow[t]{2}{*}{2.42} & Production Price (TL) & 1.69 & 1.84 & 2.31 & 1.31 & 1.38 & 1.46 \\
\hline & & Annual Production Amount (Year) & 6.18 & 0.94 & 0.46 & 1.21 & 0.85 & 0.36 \\
\hline \multirow{2}{*}{ VEHICLE CAPACITY } & \multirow[t]{2}{*}{1.57} & Vehicle Passenger Capacity & 1.86 & 1.52 & 1.02 & 2.20 & 1.86 & 1.52 \\
\hline & & Product Life Cycle & 2.54 & 2.18 & 1.82 & 1.45 & 1.09 & 0.91 \\
\hline \multirow{2}{*}{ PROJECT FRAMEWORK } & \multirow[t]{2}{*}{0.44} & Project Cost & 2.92 & 2.56 & 2.24 & 1.06 & 0.69 & 0.52 \\
\hline & & Project Duration (Month) & 2.25 & 2.18 & 2.25 & 1.12 & 1.07 & 1.12 \\
\hline \multirow{2}{*}{$\begin{array}{l}\text { PRODUCT DEVELOPMENT } \\
\text { PROCESS }\end{array}$} & \multirow[t]{2}{*}{1.59} & Product Development Phase (P\&D) & 2.67 & 2.23 & 1.77 & 1.33 & 1.11 & 0.88 \\
\hline & & P\&D and V\&D Collaboration Stage & 2.77 & 2.23 & 1.66 & 1.11 & 1.11 & 1.11 \\
\hline \multirow{2}{*}{$\begin{array}{l}\text { VEHICLE DESIGN } \\
\text { ACTIVITY }\end{array}$} & \multirow{2}{*}{3.97} & Vehicle Design Stage (V\&D) & 2.59 & 2.22 & 1.85 & 1.48 & 1.11 & 0.74 \\
\hline & & Design Verification Phase & 3.33 & 2.38 & 1.44 & 1.42 & 0.95 & 0.47 \\
\hline
\end{tabular}

Figure 3. The importance of the criteria in the comparison at the vehicle \& company.

\begin{tabular}{|c|c|c|c|c|c|}
\hline \multirow[b]{2}{*}{ Key Criteria } & \multicolumn{5}{|c|}{ New Vehicle Development Process Factors Global Impact Assessment } \\
\hline & $\begin{array}{c}\text { MARKETING } \\
\text { PRICE } \\
(0.242)\end{array}$ & $\begin{array}{c}\text { VEHICLE } \\
\text { CAPACITY } \\
(0.157)\end{array}$ & $\begin{array}{c}\text { PROJECT } \\
\text { FRAMEWORK } \\
(\mathbf{0 . 0 4 4 )}\end{array}$ & $\begin{array}{l}\text { STAGE-GATE } \\
\text { PROCESS } \\
(0.159)\end{array}$ & $\begin{array}{c}\text { VEHICLE DESIGY } \\
\text { ACTIVITY } \\
(0.397)\end{array}$ \\
\hline \multirow[t]{2}{*}{ Sub Criteria } & $\begin{array}{c}\text { Sales } \\
\text { Price } \\
(0.195) \\
\end{array}$ & $\begin{array}{c}\text { Vehicle Passenger } \\
\text { Capacity } \\
(0.129) \\
\end{array}$ & $\begin{array}{c}\text { Project } \\
\text { Cost } \\
(0.029) \\
\end{array}$ & \begin{tabular}{|c|} 
Product Development \\
Phase (P\&D) \\
$(0.092)$ \\
\end{tabular} & $\begin{array}{c}\text { Vehicle Design } \\
\text { Stage (V\&D) } \\
(0.083) \\
\end{array}$ \\
\hline & $\begin{array}{c}\text { Annual Production } \\
\text { Amount } \\
(0.047) \\
\end{array}$ & $\begin{array}{c}\text { Product } \\
\text { Life Cycle } \\
(\mathbf{0 . 0 2 8}) \\
\end{array}$ & $\begin{array}{c}\text { Project } \\
\text { Duration } \\
(0.015) \\
\end{array}$ & $\begin{array}{c}\text { P\&D and V\&D } \\
\text { Collaboration Stage } \\
(0.067) \\
\end{array}$ & \begin{tabular}{|c|} 
Design Verification \\
Phase \\
$(0.314)$ \\
\end{tabular} \\
\hline Alternative & $\begin{array}{c}\text { MF1 } \\
(0.288) \\
\end{array}$ & $\begin{array}{c}\text { MF2 } \\
(0.202) \\
\end{array}$ & $\begin{array}{c}\text { MF3 } \\
(0.161) \\
\end{array}$ & $\begin{array}{c}\text { BF2 } \\
(0.112) \\
\end{array}$ & $\begin{array}{c}\text { BF3 } \\
(0.091) \\
\end{array}$ \\
\hline
\end{tabular}

Figure 4. AHP comparison model and EC software impact rates.

selection (process), are the output of the new product development process (Figure 4). Therefore, these criteria both affect the working model and are evaluated in the design process-oriented test of the market results of the benchmarking firms. Figure 5, shows the result matrix, which includes the effect rates of the main and sub-criteria obtained by the EC software.

The importance impact rates of the development stages that affect the global new product design, as determined by the AHP method, are explained in Figure 5. In Figure 5, the values reflecting the comparison selection of alternative vehicles (competing automotive company products) are given. Under development processes, the effect rates of alternative vehicles, which reflect the market performance of the final product, have been discussed in order to reveal the steps involved in the design of the new vehicle, as mentioned earlier, which contribute to the globalization of the new vehicle. As seen in Figure 2, the new product development phase differences used by the automotive companies in the increasing competition conditions have a dominant effect on the new vehicle. The design stages, which are effective on the development of the global new product that the participants (automotive and product development process managers) define, have been calculated in the importance of these criteria along with the impact rates overlapping with the market performance of the new vehicle. When the results are evaluated in terms of decision-makers, the main reason why MF type automotive companies who develop new products on a global scale is more preferable is the $31.4 \%$ rate of design validation stages that lead to the guiding role of the project results. In this computer environment, the new developing design verification steps constitute the most preferred criterion among the participants. In addition, the design validation steps correspond to the results of the dominant market performance of the product belonging to this group, together with the determination of the use of MF type automotive companies in vehicle design 

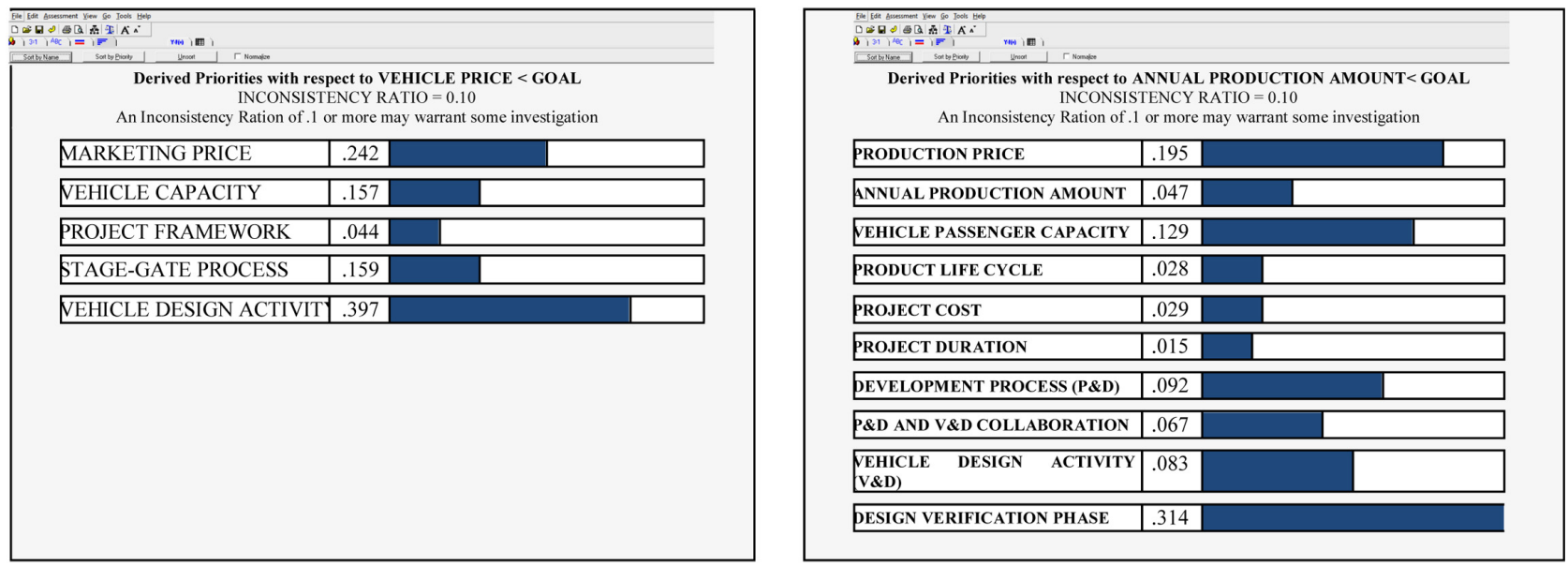

Figure 5. Comparison matrix, main and sub-criteria (EC software view).

stages. In the study, when the factors affecting the improved vehicles introduced to the market under increasing competition are evaluated, it is observed that the criteria with the lowest importance are the project time by the decision makers. In this case, it is concluded that the decision of the decision makers (automotive company managers) under a different scientific approach is more important than project time. Figure 6, shows the effect rates of automotive company products under the criteria. The effect rate of the alternatives obtained from the use of EC software is highly valued in automotive products developing global products as will be seen in Figure 6.

In the application study, the weight ratios of the design stages defined by the participants in the globalization of the product and the market performance parameters of the new vehicle were compared. While market performance evaluation of vehicles is made, the market information of the products belonging to the automotive companies performing the same class product, manufacturing and design activities in the same region are formed by the use of a statistical data archive belonging to a neutral official institution. The stages of product development used by the participants for their companies were listed by comparing the automotive companies included in the research. Therefore, the names of the participants were questioned in one on one interview by taking into consideration the step definitions of the participants. The comparison results are shown in Figure 6. The results of the AHP method performed through EC software can be summarized as follows:

- The number of employees involved in new product development and vehicle design stages shows the intensive use of such criteria. As it is seen in Figure 6 , the values of the automotive companies and the new product development processes, which are under competition, are compared with the proposed approach and the values obtained correspond with the market performances of the companies in question. In the study directed by the company managers, it is seen that design validation stages have an important role in the globalization of the new vehicle among the product development processes. This 


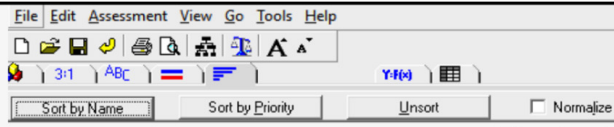

\begin{tabular}{|c|c|l|l|}
\hline MF1 & .288 & \\
\hline \hline MF2 & .202 & & \\
\hline \hline MF3 & .161 & & \\
\hline \hline BF1 & .137 & & \\
\hline \hline BF2 & .112 & & \\
\hline \hline BF3 & .091 & & \\
\hline
\end{tabular}

Figure 6. Comparative effect rates of alternative automotive company vehicles (EC software view).

can be explained by the fact that the weight of the relevant sub-criterion in the AHP model is rather high (0.314) under that main criterion, and that the alternative corresponding to the criterion in the decision model is in higher priority ratios. In other words, since the main criterion weights as a result of the evaluation of the participants and the order of importance of the alternative vehicles are the same, the matching situation occurs. This is due to the overlap of the same point of view or order in the process of determining the weight of the benchmark for testing the proposed approach. The performance criteria for the five criteria that constitute the quantitative market data of the five criteria indicating the characteristics of alternative vehicles were initially calculated as a percentage. In other words, these quantitative criteria are calculated by comparing the percentage share of the new product with the share of market performance and the participant preference rates tested. It is seen that the proposed approach gives better results than the participant preferences in most cases under these ten criteria, and in a few cases it is equal to the market performance of the vehicle.

- In the study, firstly, the consistency rates of the criteria formed under the data obtained as a result of the interviews with the 84 participants who were informed about the new product development process in the units within the factories where the application was carried out were calculated. It was observed that 50 employees' answers were consistent with the questions given by the company executives attending the interviews and the weights given to each criterion were calculated by taking the matrices into consideration (Figure 7).

- In the first phase of the research, a simple two-stage AHP hierarchical structure with five criteria was created to reveal vehicle design stages. With the AHP model, after determining the impact of each decision-maker on the criteria, the stage of the development process defined by each decision-maker has been obtained by taking into consideration the importance of the new product development stage of automotive companies. 

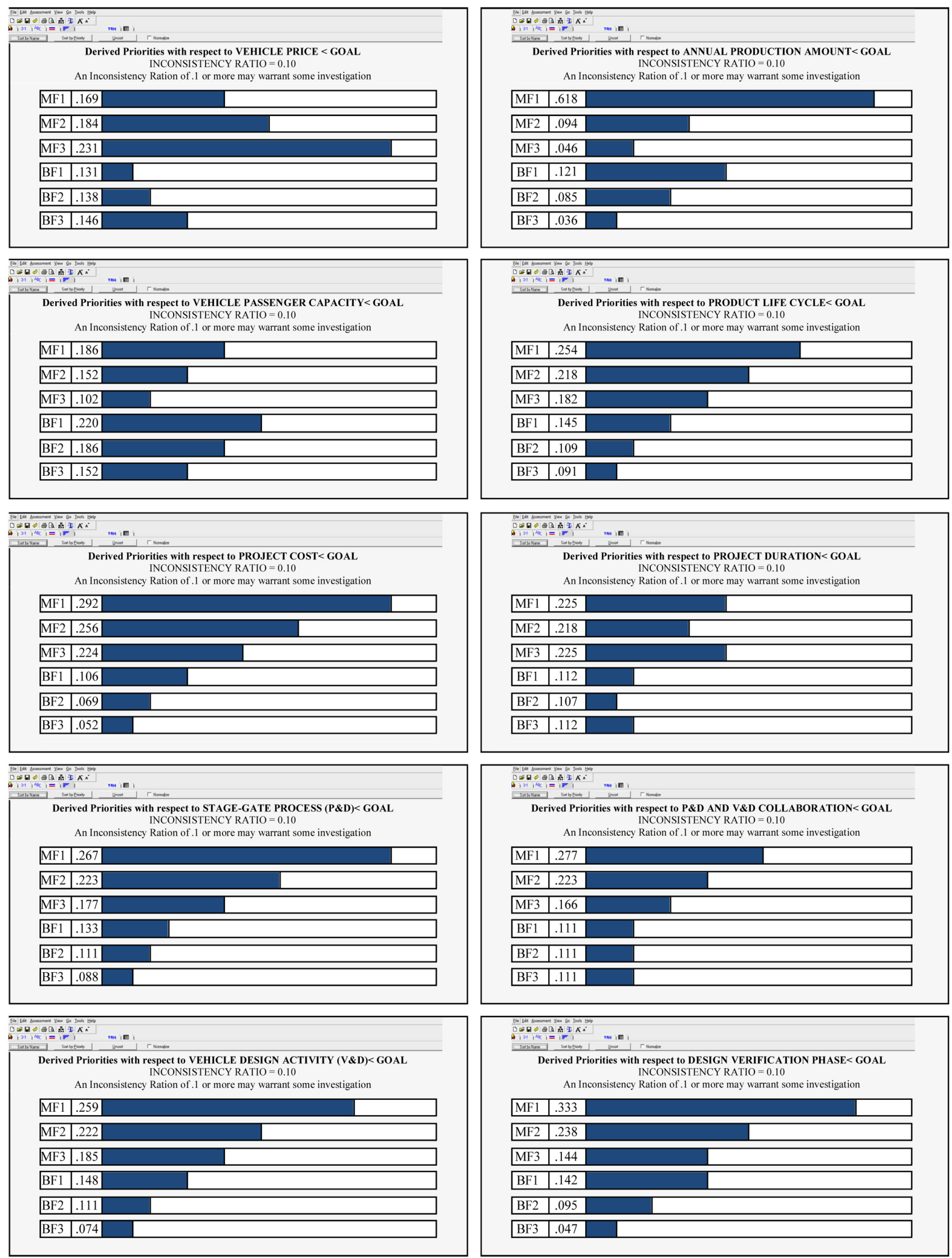

Figure 7. Product comparisons of automotive companies (EC software view). 
As seen in Figure 7, the results obtained from the EC software were transferred to the AHP effect rates under the comparison of the alternative $6 \mathrm{com}$ peting automotive firm products, consisting of 2 sub-criteria, consisting of 5 main criteria. MF1 takes the first place in the number of product design, product development process, project cost, product life cycle, production number of the automotive company's vehicle design activities and design verification stages. The MF1 automotive company's market leading position in the market performance leadership and new product development process is the first in seven of the 10 benchmarks. Alternative companies and criteria that should be evaluated in Figure 7, is: The vehicle capacity value of $\mathrm{BF} 1$, the vehicle sales price criterion of MF3 company and the project time of MF3 company. It is observed that the short project time and the low price strategy of the MF3 Company have successful secondary results under the AHP model. The performance results of the AHP method through EC software are shown in Figure 7.

The average value of each sub-criterion, taking into account the order of importance of each sub-criterion, is calculated in Figure 7 for the purpose of showing which main competitor firms are met at the level of the main criteria. In Figure 7, the larger the value (convergence of 1 or 0.999 ) indicates a better result. As seen in Figure 7, the design validation stage criterion is the highest value among all main and sub criteria. While the flow of the mathematical model formed under the intended problem solving in 3 levels creates a more complex formula, there is only one structure in the actual application that takes into account the two stage criteria.

\section{Conclusions and Discussion}

In this study, AHP model EC software based fuzzy logic method has been developed for the problem of determining the stages affecting the new product design in the automotive industry on a global scale. The problem is composed of two stages (Figure 8). Therefore, in order to solve the problem, in the first stage, it was determined how new product development and vehicle design stages in automotive companies took place in practice. Then, the process of development of the equivalent vehicle and automotive company were evaluated. In the first stage of the study, benchmarking criteria have been established by taking into account the effect of design validation development processes on the final product (Figure 8). In the second stage, the market performance information of the automotive company products has been reached to test the information obtained (Figure 8). Each of the benchmarks taken into consideration is important product development steps for the global expansion of the new vehicle passing through the design phase (Figure 8). In this context, one on one interviews were made with the automotive company and development process managers and main and sub-factors were determined under the AHP method. Then, EC software was used to calculate the weight of the criteria formed by the participants with different decision structure at the firm level. The variability between the 


\begin{tabular}{|c|c|c|c|c|}
\hline \multirow{2}{*}{\multicolumn{5}{|c|}{$\begin{array}{l}\text { - Sensitivity Analysis cilecprołicecrem1.ec1 - [Dynamic] } \\
\text { 誹 File Options Window Help }\end{array}$}} \\
\hline & & & & \\
\hline \multicolumn{5}{|c|}{ 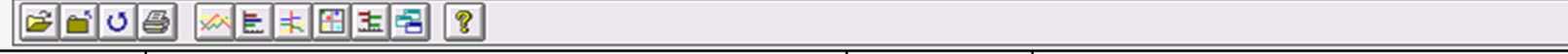 } \\
\hline $31.4 \%$ & Design Verification Phase & $28.8 \%$ & MF1 & \\
\hline $19.5 \%$ & Vehicle Price (TL) & $20.2 \%$ & MF2 & \\
\hline $12.9 \%$ & Vehicle Passenger Capacity & $16.1 \%$ & MF3 & \\
\hline $9.2 \%$ & Product Development Process (P\&D) & $13.7 \%$ & BF1 & \\
\hline $8.3 \%$ & Vehicle Design Activity (V\&D) & $11.2 \%$ & BF2 & \\
\hline $6.7 \%$ & P\&D and V\&D Collaboration & $09.1 \%$ & BF3 & \\
\hline $4.7 \%$ & Annual Production Amount (Year) & & & \\
\hline $2.9 \%$ & Project Cost & & & \\
\hline $2.8 \%$ & Product Life Cycle (Year) & & & \\
\hline $1.5 \%$ & Project Duration (Month) & & & \\
\hline \multicolumn{2}{|c|}{ Open all Sensitivity Modes } & & & Ideal Mode \\
\hline
\end{tabular}

Figure 8. Sequencing of the sub-criteria affecting the globalization of the new product (EC software view).

design processes used in the research has been unified in six different structures by becoming common at the participant company level. These comparative process models were discussed together with the impact rates under the criteria and the AHP method was solved by EC software (Figure 8).

In order to test the validity of this proposed approach, the market performances of the automotive company products included in the comparison structure were evaluated under the AHP model (Figure 9). Therefore, with the results of the obtained EC software, the market performance parameters of the competing automotive company vehicles in the comparison constitute the test values. According to the test results, the proposed approach overlaps. In this context, the main and sub-criteria of each competing automotive company product are calculated numerically (Figure 9). According to the result of the proposed approach with the AHP model, it is revealed that the use of design validation phase as a sub-criterion has a significant effect on the globalization performance of the vehicle (Figure 9). In addition, when the sub-criteria are compared at the level of the competing automotive firm product, the results vary in the results of the study despite the low impact of the project duration and vehicle price criteria (Figure 9).

In this study, 14 vehicle design phases and 24 new product development steps were determined in automotive company applications (Figure 9). The design verification steps of the automotive companies involved in the research, along with the vehicle design stages, as well as the new product development step collaborations play an important role in globalization dissemination. It has been revealed that the design validation criteria have an effective role in the new product development phase definitions of participant automotive company managers and the market performance values of the vehicle. In the first stage of 


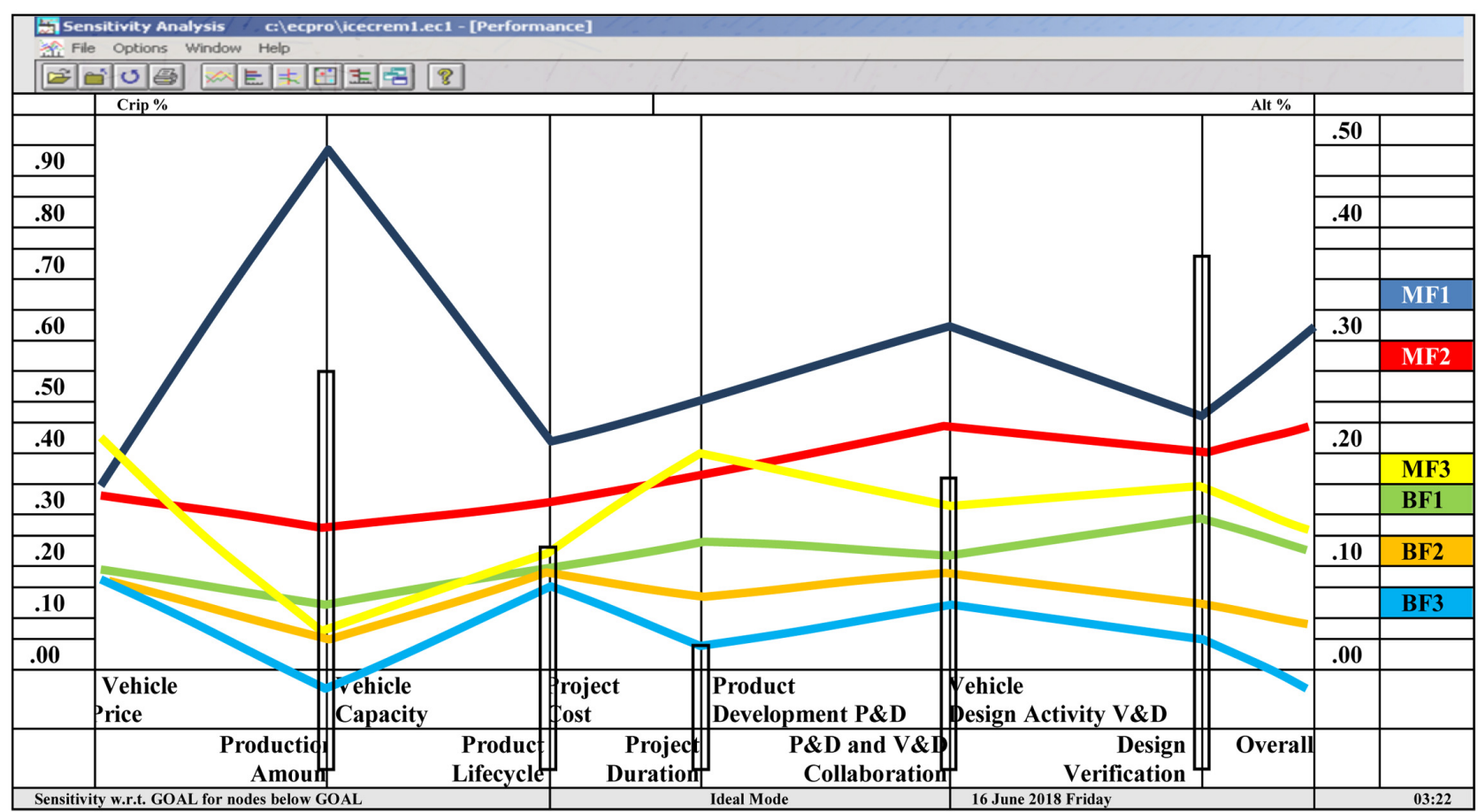

Figure 9. The results; Performance analysis of the criteria (EC software view).

the two-step study, new product development stages were defined in the automotive company (Figure 9). In the second part, the impact significance levels of these stages were determined (Figure 9). Therefore, as an exemplary application, this problem can be easily adapted to other industry and sector studies. It is thought that the proposed solution practice will take place in the global development of the automotive industry. New disciplines such as design verification activities in the automotive industry or vehicle industry are included with new technologies. It is expected that scientific publications on the development or current status of the automotive industry will increase. The new product development stages currently discussed in this study or the factors that affect vehicle design activities and current fiction can provide insight into the process analysis of developing sectors other than automotive industry. In addition to this, in the process development, studies on increasing the scientific diversity or optimization of the response of the new product under variable conditions can be presented.

\section{Conflicts of Interest}

The authors declare no conflicts of interest regarding the publication of this paper.

\section{References}

[1] Candi, M. and Gemser, G. (2010) An Agenda for Research on the Relationship between Industrial Design and Performance. International Journal of Design, 4, 67-77.

[2] Person, O., Snelders, D. and Schoormans, J. (2016) Assessing the Performance of Styling Activities: An Interview Study with Industry Professionals in Style-Sensitive 
Companies. Design Studies, 42, 33-55. https://doi.org/10.1016/j.destud.2015.10.001

[3] Paker, F. A., Alppay, C. and Sertyesilisik, B. (2018) Use of the AHP Methodology in Vehicle Design Process Dynamics: Determination of the Most Effective Concept Phases for the New Automotive Product. Journal of Transportation Technologies, 8, 312-330. https://doi.org/10.4236/jtts.2018.84017

[4] Ullman, D.G. (1992) The Mechanical Design Process. 2nd Edition, McGraw-Hill, New York.

[5] Pahl, G. and Beitz, W. (1996) Engineering Design: A Systematic Approach. Springer, New York. https://doi.org/10.1007/978-1-4471-3581-4

[6] Otto, K. and Wood, K. (2001) Product Design: Techniques in Reverse Engineering, Systematic Design and New Product Development. Prentice-Hall, New York.

[7] Atilola, O., Tomko, M. and Linsey J. (2016) The Effects of Representation on Idea Generation and Design Fixation: A Study Comparing Sketches and Function Trees. Design Studies, 42, 110-136. https://doi.org/10.1016/j.destud.2015.10.005

[8] Stevenson, H. (2008) American Automobile Advertising, 1930-1980. McFarland, Jefferson, NC.

[9] O’Neill, B. (2009) Preventing Passenger Vehicle Occupant Injuries by Vehicle Design-A Historical Perspective from IIHS. Traffic Injury Prevention, 10, 113-126. https://doi.org/10.1080/15389580802486225

[10] Geels, F.W. and Penna, C.R. (2015) Societal Problems and Industry Reorientation: Elaborating the Dialectic Issue Life Cycle (DILC) Model and a Case Study of Car Safety in the USA (1900-1995) Research Policy, 44, 67-82. https://doi.org/10.1016/j.respol.2014.09.006

[11] Brosed, J., Aguilar, J., Guillomia, D. and Santolaria, J. (2011) 3D Geometrical Inspection of Complex Geometry Parts Using a Novel Laser Triangulation Sensor and a Robot. Sensors (Basel), 11, 90-110. https://doi.org/10.3390/s110100090

[12] Soo, V.K., Compston, P. and Doolan M. (2015) Interaction between New Car Design and Recycling Impact on Life Cycle Assessment. Procedia CIRP, 29, 426-431. https://doi.org/10.1016/j.procir.2015.02.055

[13] Seidel, V.P. and O'Mahony, S. (2014) Managing the Repertoire: Stories, Metaphors, Prototypes, and Concept Coherence in Product Innovation. Organization Science, 25, 691-712. https://doi.org/10.1287/orsc.2013.0879

[14] Elverum, C.W., Welo, T. and Steinert, M. (2014) The Fuzzy Front End: Concept Development in the Automotive Industry. ASME, Design Theory and Methodology, Buffalo.

[15] Stylidis, K., Rossi M., Wickman, C. and Söderberg, R. (2016) The Communication Strategies and Customer's Requirements Definition at the Early Design Stages: An Empirical Study on Italian Luxury Automotive Brands. Procedia CIRP, 50, 553-558. https://doi.org/10.1016/j.procir.2016.04.062

[16] Cajal, C., Santolaria, J., Acero, R. and Pueo, M. (2015) Introducing Design for Verification. Procedia Engineering, 132, 772-779.

[17] Remiel, F.M., Cauvin, A. and Ferrarini, A. (2015) Verification of Design Rules as an Evaluation Method during the Reconfiguration Process of Production Systems. Papers Online, 48, 1676-1681. https://doi.org/10.1016/j.ifacol.2015.06.327

[18] Chapurlat, V. (2013) UPSL-SE: A Model Verification Framework for Systems Engineering. Computers in Industry, 64, 581-597.

[19] Jauregui-Becker, J. and Wits, W. (2015) Enabling Lean Design through Computer 
Aided Synthesis: The Injection Moulding Cooling Case. Procedia CIRP, 37, 260-264. https://doi.org/10.1016/j.compind.2013.03.002

[20] Persson, J.G. (2016) Current Trends in Product Development. Procedia CIRP, 50, 378-383. https://doi.org/10.1016/j.procir.2016.05.088

[21] Nordlund, M., Kim, S., Tate, D., Lee, T. and Hilario, L. (2016) Axiomatic Design: Making the Abstract Concrete. Procedia CIRP, 50, 216-221. https://doi.org/10.1016/j.procir.2016.04.146

[22] Verganti, R. (1997) Leveraging on Systemic Learning to Manage the Early Phases of Product Innovation Projects. R\&D Management, 27, 377-392. https://doi.org/10.1111/1467-9310.00072

[23] Dow, P., Fortuna, J., Schwartz, D., Altringer, B., Schwartz, L. and Klemmer, R. (2012) Prototyping Dynamics: Sharing Multiple Designs Improves Exploration, Group Rapport, and Results. Design Thinking Research, 1, 47-70. https://doi.org/10.1007/978-3-642-31991-4_4

[24] Borjesson, S., Elmquist, M. and Hooge, S. (2014) The Challenges of Innovation Capability Building: Learning from Longitudinal Studies of Innovation Efforts at Renault and Volvo Cars. Journal of Engineering Technology Management, 31, 120-140. https://doi.org/10.1016/j.jengtecman.2013.11.005

[25] Saaty, L. (1980) The Analytic Hierarchy Process: Planning, Priority Setting, Resources Allocation. McGraw-Hill, New York.

[26] Erdogan, A., Saparauskas, J. and Turskis, Z. (2017) Decision Making in Construction Management: AHP and Expert Choice Approach. Modern Building Materials, Structures and Techniques. Procedia Engineering, 172, 270-276.

https://doi.org/10.1016/j.proeng.2017.02.111

[27] Mohamed, B. (2016) Sustainable Construction Management in Developing Countries.

[28] Gür, Ş., Hamurcu, M. and Eren, T. (2016) Using Analytic Network Process and Goal Programming Methods for Project Selection in the Public Institution. Les Cahiers du Mecas, 12, 36-51.

[29] Makovsek, D. (2014) Systematic Construction Risk, Cost Estimation Mechanism and Unit Price Movements. Transport Policy, 35, 135-145.

https://doi.org/10.1016/j.tranpol.2014.04.012

[30] Aziz, R. and Hafez, S. (2013) Applying Lean Thinking in Construction and Performance Improvement. Alexandria Engineering Journal, 52, 679-695.

https://doi.org/10.1016/j.aej.2013.04.008

[31] Krylovas, A., Zavadskas, E., Kosareva, N. and Dadelo, S. (2014) New KEMIRA Method for Determining Criteria Priority and Weights in Solving MCDM Problem. International Journal of Information Technology \& Decision Making, 13, 1119-1133. https://doi.org/10.1142/S0219622014500825

[32] Whyte, J., Stasis, A. and Lindkvist, C. (2015) Managing Change in the Delivery of Complex Projects: Configuration Management, Asset Information and "Big Data". International Journal of Project Management, 34, 339-351. https://doi.org/10.1016/j.ijproman.2015.02.006

[33] Hamurcu, M. and Eren, T. (2016) Çok Kriterli Karar Verme Yöntemleriyle Rayli Sistem Projelerinin Siralanmasi. 3rd International Symposium on Railway Systems Engineering, Edinburgh, 3-5 October 2016, 559-566.

[34] Zavadskas, E., Turskis, Z. and Antucheviciene, J. (2015) Selecting a Contractor by Using a Novel Method for Multiple Attribute Analysis: Weighted Aggregated Sum 
Product Assessment with Grey Values (WASPAS-G). Studies in Informatics and Control, 24, 141-150. https://doi.org/10.24846/v24i2y201502

[35] Kahraman, C., Onar, S. and Oztaysi, B. (2015) Fuzzy Multicriteria Decision-Making: A Literature Review. International Journal of Computational Intelligence Systems, 8, 637-666. https://doi.org/10.1080/18756891.2015.1046325

[36] Dong, Q. and Cooper, O. (2016) A Peer to Peer Dynamic Adaptive Consensus Reaching Model for the Group AHP Decision Making. European Journal of Operational Research, 250, 521-530. https://doi.org/10.1016/j.ejor.2015.09.016

[37] Zhou, Q., Vinh, V. and Thai, L. (2016) Fuzzy and Grey Theories in Failure Mode and Effect Analysis for Tanker Equipment Failure Prediction. Safety Science, 83, 74-79. https://doi.org/10.1016/j.ssci.2015.11.013

[38] Organ, A. and Yalçın, E. (2016) Performance Evaluation of Research Assistants by Copras Method. Social Sciences and Humanities, Vol. 1, Barcelona, 16-18 May 2016, 111-119.

[39] Kundakçı, N. and Işık, T. (2016) Integration of MACBET and COPRAS Methods to Select Air Compressor for a Textile Company. Decision Science Letters, 5, 381-394.

[40] Andonova, V. and Ruiz Pava, G. (2016) The Role of Industry Factors and Intangible Assets in Company Performance in Colombia. Journal of Business Research, 69, 4377-4384. https://doi.org/10.1016/j.jbusres.2016.03.060

[41] Koç, E. and Çetin, Ç. (2017) Marinalarda Deniz Operasyon işlemleri, Süreç analizi: Örnek olay çalişmasi. Dokuz Eylül Üniversitesi, Denizcilik Fakültesi Dergisi, 1-26.

[42] Özdemir, A. (2010) Yönetim Biliminde Araştırma Yöntemleri ve Uygulamalar. Beta Yayınclik, Istanbul.

[43] Jeston, J. and Nelis, J. (2014) Business Process Management: Practical Guidelines to Successful Implementations. Elsevier, Oxford.

https://doi.org/10.4324/9780203081327 